\title{
Increased mortality associated with weekend hospital admission: a case for expanded seven day services?
}

As evident from publications in The BMJ and elsewhere, ${ }^{12}$ one of the authors of this article (BMJ 2015;351:h4596, doi:10.1136/ bmj.h4596), Bruce Keogh, who is medical director of NHS England, is a long standing proponent of improving NHS services seven days a week. The $B M J$ should have requested that this be included in the authors' conflict of interest statement.
Keogh B. Should the NHS work at weekends as it does in the week? Yes. BMJ 2013;346:f621. doi:10.1136/bmj.f621 pmid:23430214.

2 NHS Services Seven Days a Week Forum. Summary of initial findings. 2013. https://www. england.nhs.uk/wp-content/uploads/2013/12/forum-summary-report.pdf

Published by the BMJ Publishing Group Limited. For permission to use (where not already granted under a licence) please go to http://group.bmj.com/group/rights-licensing/ permissions 